\title{
ANKS1B Gene Product AIDA-1 Controls Hippocampal Synaptic Transmission by Regulating GluN2B Subunit Localization
}

\author{
Jaafar 0. Tindi, ${ }^{1}{ }^{\circledR}$ Andrés E. Chávez, ${ }^{1}$ Svetlana Cvejic, ${ }^{1}$ EErika Calvo-Ochoa, ${ }^{1}$ Pablo E. Castillo, ${ }^{1}$ and Bryen A. Jordan ${ }^{1,2}$ \\ ${ }^{1}$ Dominick P. Purpura Department of Neuroscience, ${ }^{2}$ Department of Psychiatry and Behavioral Sciences, Albert Einstein College of Medicine, Bronx, New \\ York 10461
}

\begin{abstract}
NMDA receptors (NMDARs) are key mediators of glutamatergic transmission and synaptic plasticity, and their dysregulation has been linked to diverse neuropsychiatric and neurodegenerative disorders. While normal NMDAR function requires regulated expression and trafficking of its different subunits, the molecular mechanisms underlying these processes are not fully understood. Here we report that the amyloid precursor protein intracellular domain associated-1 protein (AIDA-1), which associates with NMDARs and is encoded by $A N K S 1 B$, a gene recently linked to schizophrenia, regulates synaptic NMDAR subunit composition. Forebrain-specific AIDA-1 conditional knock-out ( $\mathrm{cKO}$ ) mice exhibit reduced GluN2B-mediated and increased GluN2A-mediated synaptic transmission, and biochemical analyses show AIDA-1 cKO mice have low GluN2B and high GluN2A protein levels at isolated hippocampal synaptic junctions compared with controls. These results are corroborated by immunocytochemical and electrophysiological analyses in primary neuronal cultures following acute lentiviral shRNA-mediated knockdown of AIDA-1. Moreover, hippocampal NMDAR-dependent but not metabotropic glutamate receptor-dependent plasticity is impaired in AIDA- 1 cKO mice, further supporting a role for AIDA-1 in synaptic NMDAR function. We also demonstrate that AIDA-1 preferentially associates with GluN2B and with the adaptor protein $\mathrm{Ca}^{2+} / \mathrm{calmodulin}^{-}$ dependent serine protein kinase and kinesin KIF17, which regulate the transport of GluN2B-containing NMDARs from the endoplasmic reticulum (ER) to synapses. Consistent with this function, GluN2B accumulates in ER-enriched fractions in AIDA-1 cKO mice. These findings suggest that AIDA-1 regulates NMDAR subunit composition at synapses by facilitating transport of GluN2B from the ER to synapses, which is critical for NMDAR plasticity. Our work provides an explanation for how AIDA-1 dysfunction might contribute to neuropsychiatric conditions, such as schizophrenia.
\end{abstract}

Key words: CASK; endoplasmic reticulum; KIF17; NMDAR; plasticity; trafficking

\section{Introduction}

NMDARs are ligand and voltage-gated heterotetrameric ion channels composed of two obligatory GluN1 subunits and a combination of GluN2 and/or GluN3 subunits (Traynelis et al., 2010; Paoletti et al., 2013). Their expression, trafficking, and composition at synapses are critical for normal synaptic function and behavior. In the forebrain, NMDAR transmission is mediated

\footnotetext{
Received Sept. 29, 2014; revised March 23, 2015; accepted April 7, 2015

Author contributions: J.0.T., A.E.C., P.E.C., and B.A.J. designed research; J.O.T., A.E.C., S.C., E.C.--0., and B.A.J. performed research;S.C. and E.C.-0. contributed unpublished reagents/analytic tools; J.0.T., A.E.C.,P.E.C., and B.A.J. analyzed data; J.O.T., A.E.C., P.E.C., and B.A.J. wrote the paper.

This work was supported by National Institutes of Health Grants AG039521 (to B.A.J.), MH081935, and DA017392 (to P.E.C.). A.E.C. was supported by a National Alliance for Research on Schizophrenia and Depression Young Investigator Grant from the Brain \& Behavior Research Foundation and partially supported by Núcleo milenio Nu-MIND (NC 130011). J.0.T. was partially supported by T32 GM007288.

The authors declare no competing financial interests.

Correspondence should be addressed to Bryen A. Jordan, PhD, Dominick P. Purpura Department of Neuroscience, Albert Einstein College of Medicine, 1300 Morris Park Avenue, Rose Kennedy Center, Room 825, Bronx, NY 10461. E-mail: bryen.jordan@einstein.yu.edu.

A.E. Chávez's present address: Centro Interdisciplinario de Neurociencia de Valparaíso, Facultad de Ciencias, Universidad de Valparaíso, Valparaíso, Chile.

DOI:10.1523/JNEUROSCI.4029-14.2015

Copyright $\odot 2015$ the authors $\quad 0270-6474 / 15 / 358986-11 \$ 15.00 / 0$
}

primarily through GluN2A-subunit-containing and GluN2Bsubunit-containing NMDARs (Paoletti et al., 2013; SanzClemente et al., 2013), and the specific subunit GluN2B has been implicated in diverse neuropsychiatric disorders (Loftis and Janowsky, 2003; Poot et al., 2011; Moghaddam and Javitt, 2012; Paoletti et al., 2013; Snyder and Gao, 2013; Mota et al., 2014). The precise composition of NMDAR subunits at synapses is spatiotemporally controlled, giving rise to receptor assemblies with distinct functional properties (Cull-Candy and Leszkiewicz, 2004; Paoletti et al., 2013). However, the molecular mechanisms governing the trafficking and subunit composition of NMDARs at synapses are not fully understood.

NMDAR subunits are synthesized in the endoplasmic reticulum (ER; Wenthold et al., 2003a). Through unknown mechanisms, assembled receptors are exported from the ER and routed to dendritic Golgi outposts via microtubule-dependent transport (Jeyifous et al., 2009). GluN2B-containing NMDARs are transported to synaptodendritic compartments by the molecular motor KIF17 via an evolutionarily conserved tripartite protein complex composed of $\mathrm{Ca}^{2+}$ /calmodulin-dependent serine protein kinase (CASK), mammalian lin-7 protein 1 (MALS1), and munc-18-interacting 1 (Mint1; Setou et al., 2000). The membrane 

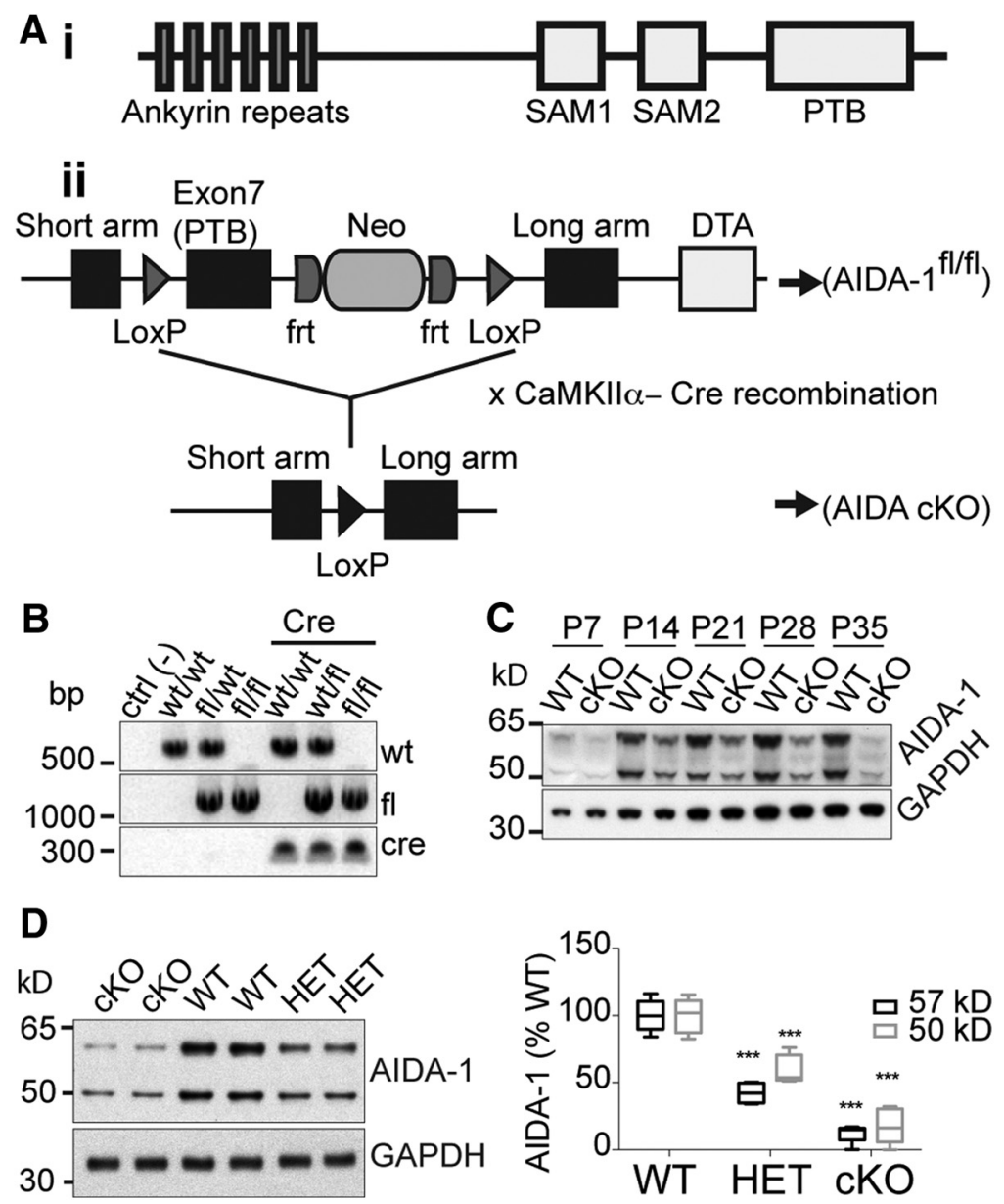

Figure 1. Generation and validation of AIDA-1 cK0 mice. $A, \boldsymbol{i}$, AIDA-1 domain schematic. SAM, Sterile $\alpha$ motif. $\boldsymbol{A}$, ii, Targeting vector and cK0 strategy: PTB domain flanked by loxP sites. AIDA-1 floxed mice (AIDA-1 ${ }^{\mathrm{fl} / f l}$ ) were crossed with CaMKIll $\alpha$ Cre mice to generate forebrain-specific AIDA-1 CKO mice. B, PCRs using mouse-tail DNA were used to test for WT and floxed (fl) alleles and Cre recombinase. WT littermates expressing Cre recombinase (wt/wt; CaMKII $\alpha$ Cre) were used as controls for all experiments. Heterozygote mice were identified as AIDA- $1^{\mathrm{f} / \mathrm{wt}} ;$ CaMKII $\alpha$ Cre and $\mathrm{CKO}$ mice were identified as AIDA- $1^{\mathrm{f} / \mathrm{fl} l} ; \mathrm{CaMKI} \alpha \mathrm{Cre}$. C, Western blot showing the progressive reduction of AIDA-1 expression in the hippocampus at different developmental stages from P7 to P35 and GAPDH (glyceraldehyde-3-phosphate dehydrogenase) control. D, Western blot showing expression of AIDA-1 splice variants (57 and $50 \mathrm{kDa}$ ) and GAPDH in hippocampus of AIDA-1 CKO mice at P35-P42. Graph shows quantification of Western blots [WT: [57 $\mathrm{kDa}], 100.0 \pm 3.8 \%$; [50 kDa], $100.0 \pm 4.0 \%$; heterozygote (HET): [57 kDa], $42.1 \pm 4.0 \%$; [50 kDa], $58.7 \pm 5.8 \%$; cK0: [57 kDa], $12.2 \pm 3.1 \% ;[50 \mathrm{kDa}], 17.8 \pm 5.8 \% ; n=4-9$ mice $],{ }^{* * *} p<0.0001$. Summary data represent mean \pm SEM.

associated guanylate kinase (MAGUK) family member SAP97 also associates with CASK to facilitate ER export and delivery of NMDARs to synapses (Jeyifous et al., 2009).

Amyloid precursor protein intracellular domain associated-1 protein (AIDA-1) is an adaptor protein previously implicated in Cajal body (Xu and Hebert, 2005) and nucleolar function (Jordan et al., 2007). It is expressed throughout the brain, including the hippocampus, and is among the most abundant proteins at postsynaptic densities (PSDs; Jordan et al., 2004, 2007; Dosemeci et al., 2007; Jacob et al., 2010), where it binds to the postsynaptic scaffolding protein PSD95 and associates with NMDARs (Jordan et al., 2007). As with NMDARs and their associated proteins (Lau and Zukin, 2007; Paoletti et al., 2013), recent studies have linked the AIDA-1 gene, ANKS1B, to neuropsychiatric disorders, including schizophrenia (McClay et al., 2011a,b; Fromer et al., 2014; Purcell et al., 2014) and autism spectrum disorders (ASDs; Pinto et al., 2010; Hu et al., 2011; Meehan et al., 2011; Uddin et al., 2014). However, how or whether AIDA-1 affects synaptic or NMDAR function is unknown.
In this study, we generated AIDA-1 conditional knock-out (cKO) mice to determine whether AIDA-1 regulates synaptic and NMDAR function. We found that AIDA-1 regulates NMDAR subunit composition and NMDAR-mediated transmission at hippocampal synapses by affecting the delivery of GluN2B-containing NMDARs to synapses. Our findings uncover a new role for AIDA-1 in NMDAR synaptic physiology and introduce a novel component of the molecular machinery that regulates the subunit-specific trafficking of NMDARs to synapses.

\section{Materials and Methods}

All experiments were approved by and were in compliance with the Albert Einstein College of Medicine Institutional Animal Care and Use Committee. All rats and mice were housed and handled at the Albert Einstein College of Medicine.

Generation of AIDA-1 cKO mice. AIDA- $\mathrm{f}^{\mathrm{fl} / \mathrm{fl}}$ mice were generated by homologous recombination using 129SVEV/C57BL6 hybrid embryonic stem (ES) cells. A targeting vector (Fig. $1 A$ ) was constructed by flanking the first exon encoding the phosphotyrosine-binding (PTB) domain with loxP sequences. For homologous recombination, the long arm and short arm (6.6 $\mathrm{kb}$ upstream and $3.6 \mathrm{~kb}$ downstream DNA sequences from the PTB exon, respectively) were included. The linearized vector was injected into 129SVEV/C57BL6 hybrid ES cells and $\mathrm{F} 1$ progeny were generated at InGenious Targeting Laboratories (State University of New York, Stonybrook). Mice were genotyped at 3 weeks [postnatal day (P) 21] by PCR screening of DNA samples from tail snips using specific primers: WT (forward, $5^{\prime}$-TCT CCC CAG AAA TCC CAC AGT G; reverse, 5' -TAC TTC AGA ATG ACA GCA GCC CGC); floxed AIDA-1 (forward, 5'-GGG GAC TGG GGA GAA CCT TCC AT; reverse, 5'-CCG GAA CAC GGC ATC AG). To generate forebrainspecific AIDA-1 cKO mice, we crossed AIDA$1^{\mathrm{fl} / \mathrm{fl}}$ mice with previously characterized CaMKII $\alpha$-Cre transgenic mice (Jackson Labs, stock \#005359). We screened AIDA-1 cKOs by PCR using the following: Cre (forward, 5' TAA AGA TAT CTC ACG TAC TGA CGG TG; reverse, $5^{\prime}$-TCT CTG ACC AGA GTC ATC CTT AGC); recombined AIDA- $1^{\mathrm{fl} / \mathrm{fl}}$ (forward: $5^{\prime}$ GGC TCT GGG GAT GCT TTT TAT G; reverse: $5^{\prime}$-ATG TCC CCA GAA TCA TAC GCC). We confirmed loss of AIDA-1 protein by Western blotting at $\mathrm{P} 35$ or later, unless otherwise stated (Fig. $1 C, D$ ).

Antibodies. AIDA-1 mouse monoclonal antibodies were generated by Abmart to the following epitopes based on the rat AIDA-1 amino acid sequence: KRILASLGDR (clone: 1A11), PIGHDGYHPT (clone: 2K9), and KSVQIDPSEQ (clone: 2B22). Hybridoma cell lines were grown in advanced hybridoma medium (Invitrogen), antibodies purified from media using protein $\mathrm{G}$ columns and each used at $0.5 \mu \mathrm{g} / \mathrm{ml}$ final concentration. Additional antibodies used were as follows: rabbit anti-GluN2A and anti-GluN2B N-terminal antibodies (Alomone Labs; 1:1000); rabbit anti-GluN2A (H-54, 1:200, for immunocytochemistry; Santa Cruz Biotechnology); mouse anti-GluN1 N-terminal (Millipore Bioscience Research Reagents; 1:1000); rabbit anti-GluA1 (Millipore; 1:1000); rabbit anti-GluA1 N-terminal (Calbiochem; 1:200); mouse anti-GluA2 N-terminal [University of California (UC) Davis, NeuroMab Facility; 
1:1000]; mouse anti-PSD95 (clone K28/43, UC Davis, NeuroMab Facility; 1:5000); mouse anti-CaMKII $\alpha$ (Abcam; 1:5000); mouse anti-CASK and mouse anti-SAP97 (UC Davis, NeuroMab Facility; 1:2000); goat anti-KIF17 (Santa Cruz Biotechnology; 1:200); rabbit anti-calnexin (Genescript; 1:5000); anti-Golgi 58K protein (Abcam; 1:500).

Cell culture, transfection, transduction, and immunocytochemistry. Primary cortical and hippocampal cultures were prepared from Sprague Dawley rat embryos at embryonic day 18 as previously described (Osten et al., 2000). Transfection of primary neuronal cultures [at 7-11 d in vitro (DIV)] or HEK cells was performed with vectors for the following: mKATE2-AIDA-1 (57 kDa isoform), eGFP-tagged GluN2A (Addgene plasmid 45445), GluN2B (Addgene plasmid 45447; Barria and Malinow, 2002), CASK (gift from Brett Abrahams, Albert Einstein College of Medicine), or YFP-KIF17 (gift from William Green, University of Chicago) using Lipofectamine 2000 (Invitrogen) following the manufacturer's instructions. Lipofectamine-transfected neurons (see Fig. $6 E$ ) were imaged at DIV 10-14. AIDA-1-specific shRNAs were cloned into pTRIP lentiviral vectors. The shRNA sequences were as follows: shAIDA\#1 $\left(5^{\prime}-\right.$ GCAATGTTATGGAAGATCA-3'), shAIDA\#2 (5'-GCTCAACTG CCCCGTATTT- $3^{\prime}$ ), and scrambled shNT (5'-CGTAAGCTGAGA TAACTGA-3'). Lentiviruses were generated by triple transfection of pTRIP, psPAX2, and pMD.G into 293FT cells (Invitrogen) and infectious particles purified from the media. Neurons were transduced at 7-8 DIV using a multiplicity of infection of 0.5 and incubated for 5-14 d. Transduced neurons were processed for immunocytochemistry using standard conditions at DIV 16-21. Images were analyzed using ImageJ software.

Hippocampal slice and primary neuronal culture electrophysiology. Acute transverse hippocampal slices ( $400 \mu \mathrm{m}$ thick) were prepared from 5-6-week-old WT and AIDA-1 cKO mice of either gender. Briefly, hippocampi were isolated in a cutting solution containing the following (in mM): 215 sucrose, $2.5 \mathrm{KCl}, 26 \mathrm{NaHCO}_{3}, 1.6 \mathrm{NaH}_{2} \mathrm{PO}_{4}, 1 \mathrm{CaCl}_{2}, 4 \mathrm{MgCl}_{2}$, $4 \mathrm{MgSO}_{4}$, and 20 glucose. Thirty minutes after sectioning, slices were incubated in an artificial CSF (ACSF) recording solution containing the following (in mM): $124 \mathrm{NaCl}, 2.5 \mathrm{KCl}, 26 \mathrm{NaHCO}_{3}, 1 \mathrm{NaH}_{2} \mathrm{PO}_{4}, 2.5$ $\mathrm{CaCl}_{2}, 1.3 \mathrm{MgSO}_{4}$, and 10 glucose equilibrated with $95 \% \mathrm{O}_{2} / 5 \% \mathrm{CO}_{2}, \mathrm{pH}$ 7.4. The slices were incubated in this solution for $\geq 30 \mathrm{~min}$ before recordings.

All experiments, except where indicated, were performed at $28 \pm 1^{\circ} \mathrm{C}$ in a submersion-type recording chamber perfused at $\sim 1-2 \mathrm{ml} / \mathrm{min}$ rate with ACSF supplemented with the $\mathrm{GABA}_{\mathrm{A}}$ receptor antagonist picrotoxin (PTX; $100 \mu \mathrm{M}$ ). Extracellular field potentials (fEPSPs) were recorded with a patch pipette filled with $1 \mathrm{~mm} \mathrm{NaCl}$ and placed in the $\mathrm{CA} 1$ stratum radiatum $(\sim 100 \mu \mathrm{m}$ deep). EPSCs were recorded from CA1 pyramidal neurons voltage-clamped at -60 and $+40 \mathrm{mV}$ using patchtype pipette electrodes $(\sim 3-4 \mathrm{M} \Omega$ ) containing the following (in $\mathrm{mm}$ ): 131 Cs-gluconate, $8 \mathrm{NaCl}, 1 \mathrm{CaCl}_{2}, 10$ EGTA, 10 glucose, $10 \mathrm{HEPES}, \mathrm{pH}$ $7.2,292 \mathrm{mmol} / \mathrm{kg}$ osmolality. fEPSPs and EPSCs were evoked by stimulating Schaffer collateral inputs with a monopolar electrode filled with ACSF and positioned $\sim 100-150 \mu \mathrm{m}$ away from the recording pipette. Miniature excitatory currents (mEPSCs) were recorded at $30^{\circ} \mathrm{C}$ from CA1 pyramidal neurons voltage clamped at $-60 \mathrm{mV}$ in ACSF containing $100 \mu \mathrm{M}$ PTX and $0.5 \mu \mathrm{M}$ TTX. mEPSCs were identified using a minimal threshold amplitude ( $\geq 5 \mathrm{pA}$ ) and analyzed using $10 \mathrm{~min}$ continuous recordings. Typically, series resistance (range, $8-15 \mathrm{M} \Omega$ ) was monitored throughout the experiment with a $-5 \mathrm{mV}, 80 \mathrm{~ms}$ voltage step, and cells that exhibited significant change in series resistance $(>20 \%)$ were excluded from analysis.

For recording of primary hippocampal cultures (see Fig. $5 D, E$ ), the extracellular and intracellular solutions were as described above. Wholecell recordings were performed in shNT-expressing and shAIDA\#2expressing neurons voltage clamped at $+40 \mathrm{mV}$ in ACSF supplemented with NBQX $(5 \mu \mathrm{M})$ and PTX $(50 \mu \mathrm{M})$, to block AMPA/kainate and GABA receptors, respectively. Synaptic currents were obtained by electrical stimulation focally applied through a patch-type pipette filled with ACSF and placed close to the cell body of the recorded neuron $(<50 \mu \mathrm{m})$. Each experiment has been repeated in $\geq 6$ independent batches of cultures transfected on DIV 7 and recorded at DIV 12-21.

Pharmacological agents $\left(\mathrm{Zn}^{2+}\right.$ and Ro 25-6981) were bath applied after establishment of a stable baseline ( $\sim 10 \mathrm{~min})$, and their effects were measured after responses reached a new steady state (typically $>15 \mathrm{~min}$ ). Drugs were obtained from Sigma-Aldrich $\left(\mathrm{Zn}^{2+}, \mathrm{PTX}\right)$ and Tocris Bioscience (Ro 25-6981), except NBQX, which was obtained from the National Institute of Mental Health's Chemical Synthesis and Drug Supply Program. Stock solutions were prepared in water or DMSO (PTX, NBQX) and added to the ACSF as needed. Total DMSO in the ACSF was maintained at $<0.1 \%$. For $\mathrm{Zn}^{2+}$ experiments (see Fig. $4 B$ ), $10 \mathrm{~mm}$ tricine ( $N$-[tris(hydroxymethyl)methyl]glycine) was added to the ACSF to buffer endogenous $\mathrm{Zn}^{2+}$. In the tricine-ACSF solution, $\mathrm{NaHCO}_{3}$ was increased up to $27 \mathrm{~mm}$ and the $\mathrm{pH}$ was adjusted with $\mathrm{NaOH}$. A total extracellular concentration of free $\mathrm{Zn}^{2+}$ of $200 \mathrm{~nm}$ was estimated by adding $40 \mu \mathrm{M} \mathrm{ZnCl}_{2}$ to the tricine-ACSF.

Long-term potentiation (LTP) was induced after $15 \mathrm{~min}$ of stable baseline by high-frequency stimulation (HFS; see Fig. $6 \mathrm{~A}$ ) or by thetaburst stimulation (TBS; see Fig. 6B). HFS consisted of four $100 \mathrm{~Hz}$, 100 -stimuli bursts delivered $20 \mathrm{~s}$ apart. TBS consisted of a series of 10 bursts of five stimuli ( $100 \mathrm{~Hz}$ within the burst, $200 \mathrm{~ms}$ interburst interval), which was repeated four times (5 s apart). Long-term depression (LTD) was induced by low-frequency stimulation $(900$ pulses at $1 \mathrm{~Hz}$; NMDAR-LTD; see Fig. $6 C$ ) or by transient ( $5 \mathrm{~min}$ ) bath application of 50 $\mu \mathrm{M}(\mathrm{S})$-3,5-dihydroxyphenylglycine, a group I mGluR agonist (mGluRLTD; see Fig. 6D). The magnitude of LTP or LTD was compared between WT and cKO genotypes 35-40 min after induction. All electrophysiological recordings and analyses were done blind to the genotype of the mice.

All recordings were performed using a Multiclamp 700A amplifier (Molecular Devices), elicited at $20 \mathrm{~s}$ intervals, filtered at $2.2 \mathrm{kHz}$, and acquired at $5 \mathrm{kHz}$ using a custom-made software written in Igor Pro 4.09A (Wavemetrics). NMDAR-EPSC decay kinetics was fitted with a single exponential function using OriginPro 8.6 software (OriginLab).

Biochemical fractionation-PSDs, ER, and Golgi. PSD fractions were prepared as previously described using "the short method" (Jordan et al., 2004). Golgi and ER membranes were prepared following the Alternate Protocol 2 outlined by Graham (2001). Pellets from isolated fractions were resuspended in 2\% SDS, $50 \mathrm{~mm}$ Tris, $\mathrm{pH}$ 7.4, buffer containing a protease inhibitor mixture, and resolved by SDS-PAGE and Western blotting. Golgi and ER fractions were identified using anti-58K Golgi protein antibody and anti-calnexin antibody, respectively.

Immunoprecipitation. $\mathrm{P} 42-\mathrm{P} 45$ mice were killed using $\mathrm{CO}_{2}$ and their hippocampi were quickly dissected and Dounce homogenized 20 times in lysis buffer containing the following: $25 \mathrm{~mm}$ Tris, $\mathrm{pH} 7.4,150 \mathrm{~mm}$ $\mathrm{NaCl}, 1 \% \mathrm{Tx}-100$, and $0.1 \%$ SDS containing protease inhibitor mixture (Thermo Scientific) and 2 mm EDTA. Lysates were briefly sonicated and incubated at $4^{\circ} \mathrm{C}$ with rocking for $1 \mathrm{~h}$ and then centrifuged at $20,000 \times g$ for $30 \mathrm{~min}$. Five hundred micrograms of lysate were incubated with $2 \mu \mathrm{g}$ of primary antibody overnight at $4^{\circ} \mathrm{C}$ and immune complexes recovered with protein $\mathrm{G}$ agarose preblocked with $5 \%$ BSA/PBS. Immunoprecipitations were then processed by standard methods and Western blots analyzed by densitometry using ImageJ. For comparative quantification (see Fig. 6A, $B$ ), signal from the immunoprecipitation lane was normalized to the input signal.

Statistical analysis. An unpaired, two-tailed $t$ test was used for comparison of two groups. $p<0.05$ was considered statistically significant. For $>2$ groups, a one-way ANOVA was used, followed by a post hoc unpaired, two-tailed $t$ test with Tukey's correction for multiple comparisons. For electrophysiological experiments, statistical analysis was performed using one-way ANOVA at the $p<0.05$ significance level in OriginPro 8.6 software (OriginLab). Unless otherwise stated, data are presented as mean \pm SEM and illustrated traces are averages of 20-31 responses. For all figures, $p$ values from comparisons where a statistically significant difference was found are indicated as follows: ${ }^{*} p<0.05,{ }^{* *} p<0.01$, and ${ }^{* * *} p<0.001$.

\section{Results}

\section{Generation of AIDA- 1 cKO mice}

To examine AIDA-1 function, we generated forebrain and neuron-specific AIDA-1 knock-out mice (AIDA-1 cKO). AIDA-1 is encoded by the exceptionally large ANKS1B gene (1.2 
A
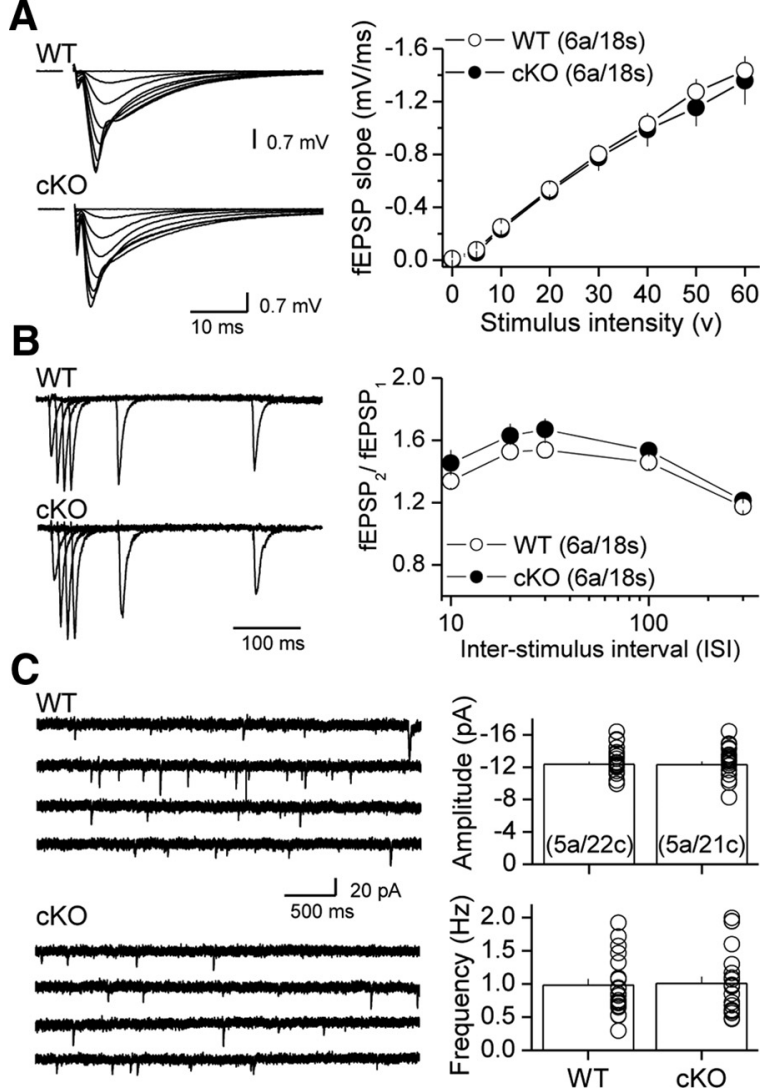

Figure 2. Excitatory transmission at hippocampal Sch-CA1 synapses in AIDA-1 CK0 mice. $A$, $\boldsymbol{B}$, Loss of AIDA-1 did not significantly alter $(\boldsymbol{A})$ input- output function or $(\boldsymbol{B})$ paired-pulse ratio measured at 10,30, 100, and 300 ms interstimulus intervals (ISI). C, Representative AMPAR$\mathrm{mEPSC}$ traces (left) and summary plots (right) showing no change in AMPAR-mEPSC amplitude or frequency in WT and AIDA-1 cKO neurons. In all panels, summary data represent the mean \pm SEM. Number of cells (c), slices (s), and animals (a) are indicated in parentheses.

megabase). While multiple AIDA-1 splice isoforms have been reported (Ghersi et al., 2004a,b; Xu and Hebert, 2005; Jordan et al., 2007), the PTB domain is conserved across all known isoforms. Therefore, we flanked the exon encoding a portion of the PTB domain with loxP sequences and mated floxed AIDA-1 mice (AIDA- ${ }^{\mathrm{fl} / \mathrm{fl}}$ ) with CaMKII $\alpha$-Cre mice for postnatal forebrain and neuron-specific ablation (Fig. $1 A$ ). CaMKII $\alpha$-driven Cre expression is observed as early as 2 weeks postnatally and reaches mature levels by P28 (Tsien et al., 1996), which enables the study of AIDA-1 function in neurons at later developmental stages, thereby mitigating concerns regarding compensatory developmental effects. Mice were genotyped at 3 weeks of age by PCR using specific primers for WT and floxed AIDA-1 alleles, and Cre recombinase (Fig. $1 B$ ). Western blot analysis using newly generated AIDA-1 monoclonal antibodies (see Materials and Methods) confirmed a progressive reduction in AIDA-1 levels in the forebrain of cKO mice from P7 to P35 (Fig. 1C), which is well after Cre has reached peak levels (Tsien et al., 1996). Interestingly, AIDA-1 is barely detectable at P7 but increases steadily through P35, showing that its expression is developmentally regulated. We confirmed that homozygous, $\mathrm{AIDA}^{\mathrm{fl} / \mathrm{fl}} \mathrm{CaMKII} \alpha \mathrm{Cre}$ (cKO) mice had a $80-90 \%$ reduction, while heterozygous, $\operatorname{AIDA}{ }^{\mathrm{fl} / \mathrm{wt}} \mathrm{CaMKII} \alpha \mathrm{Cre}$ (HET) mice had a $30-50 \%$ reduction in AIDA-1 protein expression in the hippocampus at P35 (Fig. 1D). AIDA-1 cKO mice appeared grossly normal and were indistinguishable from littermate controls.
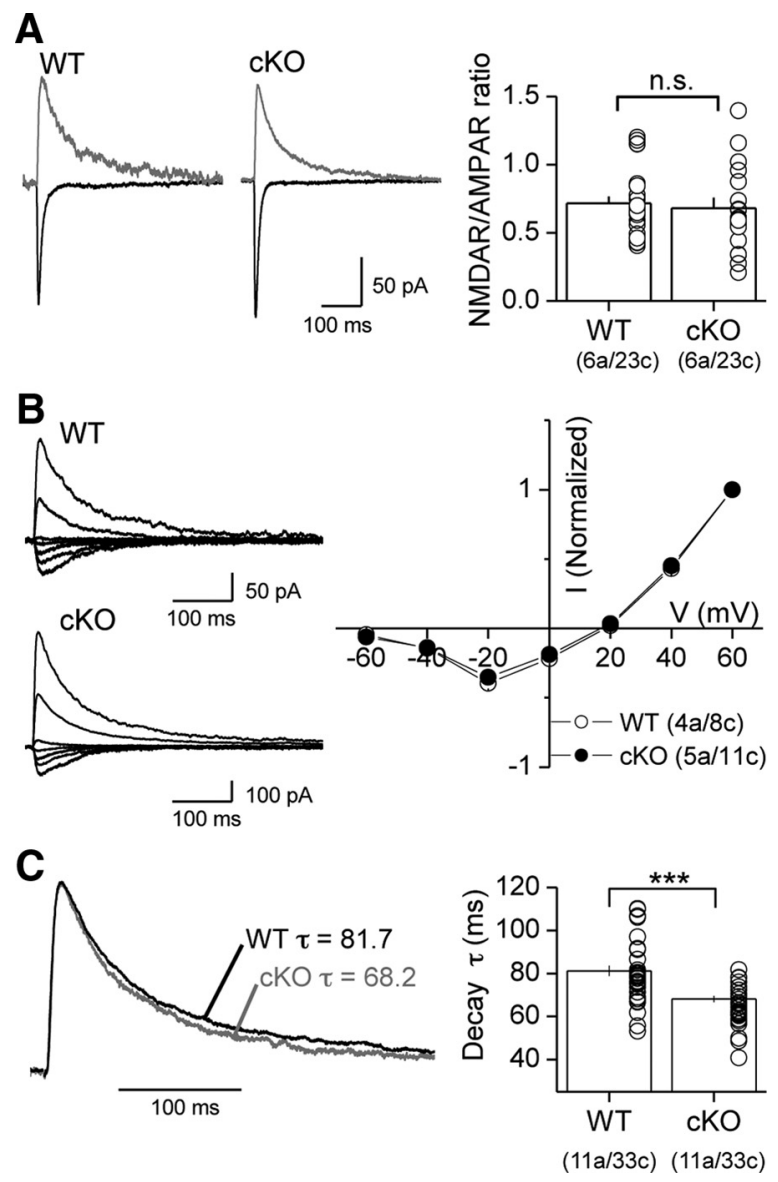

Figure 3. Synaptic NMDAR transmission in AIDA-1 cKO mice. $\boldsymbol{A}$, Representative averaged EPSCs (left) and summary data (right) showing that the NMDAR/AMPAR ratio was similar between WT and AIDA-1 cKO neurons (WT, $0.71 \pm 0.05$; CK0, $0.68 \pm 0.07, p=0.71$ ). $\boldsymbol{B}$, NMDAREPSCs recorded at different holding potentials in WT and AIDA-1 CKO neurons; representative averaged traces (left) and I-V plot (right). C, Normalized NMDAR-EPSCs (left) and summary data (right) showing faster NMDAR decay kinetics in AIDA-1 cKO compared with WT mice (WT, $81.2 \pm 2.4 \mathrm{~ms} ;$ (KO, $68.2 \pm 1.5 \mathrm{~ms}$ ). Summary data represent the mean \pm SEM and the number of cells (c), and animals (a) are indicated in parentheses. ${ }^{* * *} p<0.001$. n.S., Not significant.

\section{Loss of AIDA-1 selectively alters synaptic NMDAR subunit composition}

AIDA-1 is highly expressed in the hippocampus (Jacob et al., 2010) and is enriched at PSDs in dendritic spines (Jordan et al., 2004, 2007; Dosemeci et al., 2007; Jacob et al., 2010). To characterize the effect of AIDA-1 deletion on excitatory synaptic transmission, we monitored Schaffer collateral to CA1 pyramidal cell synapses (Sch-CA1) in acute hippocampal slices from AIDA-1 cKO mice and littermate controls. We found that input-output function (Fig. 2A) and paired-pulse ratio (Fig. 2B) were unaltered in AIDA-1 cKO mice. Furthermore, we observed no differences in the amplitude or frequency of AMPAR-mediated mEPSCs (Fig. 2C). These results strongly suggest that loss of AIDA-1 does not affect AMPAR-mediated synaptic transmission or glutamate release probability.

Since AIDA-1 associates with NMDARs (Jordan et al., 2007), we characterized NMDAR-mediated synaptic transmission. We analyzed NMDAR/AMPAR ratios by recording evoked AMPAR-mediated postsynaptic currents (EPSCs) at $-60 \mathrm{mV}$ and NMDAR-mediated EPSCs at $+40 \mathrm{mV}$ in the presence of 10 $\mu \mathrm{M}$ NBQX (Fig. $3 A$ ), and also analyzed NMDAR-EPSC currentvoltage (I-V) plots (Fig. 3B). Both NMDAR/AMPAR ratios and 


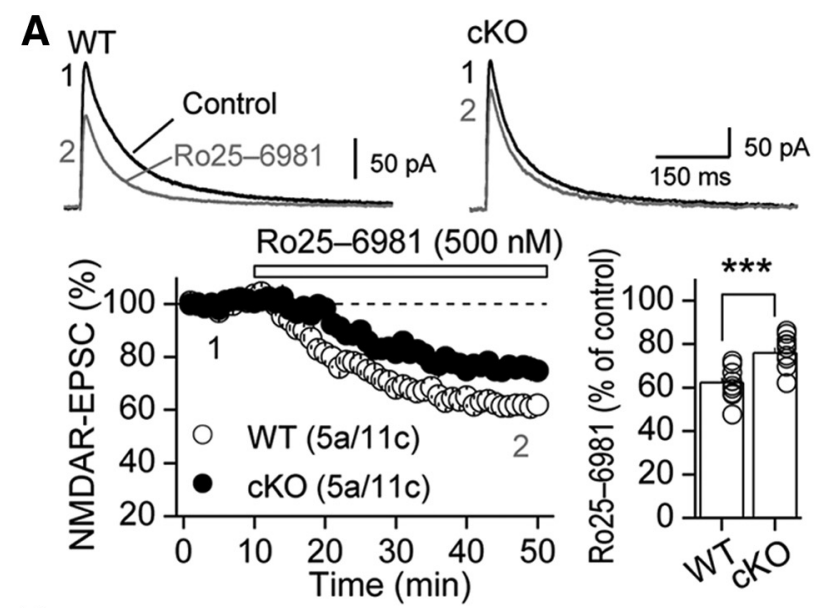

B
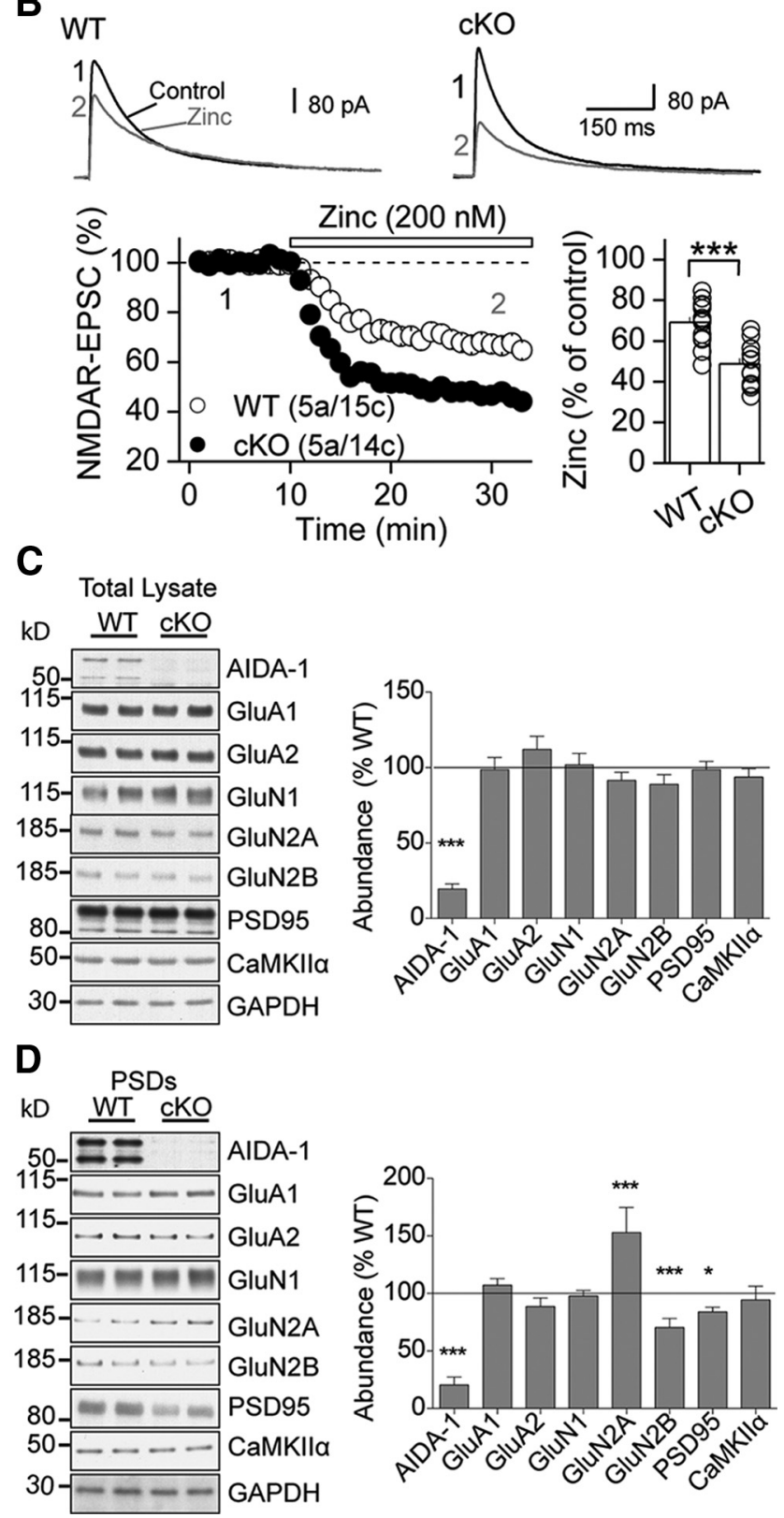

Figure 4. Altered GluN2A-mediated and GluN2B-mediated synaptic transmission and synaptic expression in AIDA-1 CKO mice. $\boldsymbol{A}$, Averaged NMDAR-EPSCs (top) and summary data (bottom) showing less sensitivity to the selective GluN2B antagonist Ro25-6981 (500 nm) in AIDA-1
I-V plots were indistinguishable between genotypes. However, NMDAR-EPSCs showed significantly faster decay kinetics in AIDA-1 cKO mice compared with WT controls (Fig. 3C), which could reflect a change in synaptic NMDAR subunit composition (Cull-Candy and Leszkiewicz, 2004; Paoletti et al., 2013). To test this possibility, we used Ro25-6981 (500 nM) and low doses of $\mathrm{Zn}^{2+}$ (200 nM; see Materials and Methods) to selectively block GluN2B-containing and GluN2A-containing NMDARs, respectively. We found that NMDAR-EPSCs in AIDA-1 cKO mice were less sensitive to Ro25-6981 (Fig. 4A) but more sensitive to $\mathrm{Zn}^{2+}$ (Fig. 4B) than littermate controls.

This change in sensitivity to Ro25-6981 and low doses of $\mathrm{Zn}^{2+}$ suggests a decrease in the abundance of GluN2B-containing NMDARs and a corresponding increase in GluN2A-containing NMDARs at synapses in AIDA-1 cKO mice. To confirm this we isolated hippocampi from cKO mice and WT littermates and measured protein abundance using SDS-PAGE and Western blotting. However, we found no changes in the overall abundance of NMDAR or AMPAR subunits or other synaptic components in whole hippocampal lysates (Fig. 4C), suggesting that transcription, translation, or degradation of these proteins were unaltered in AIDA-1 cKO mice. In contrast, we observed an increase in the abundance of GluN2A subunits and a decrease in GluN2B subunits in biochemically isolated PSDs from hippocampi of AIDA-1 cKO mice compared with controls (Fig. 4D). There was also a small but significant reduction of PSD-95 in AIDA-1 cKO mice. Levels of synaptic GluN1 or AMPAR subunits GluA1 and GluA2 were unchanged (Fig. 4D).

To validate whether loss of AIDA-1 alters NMDAR subunit composition, we used lentiviral-delivered shRNAs to knockdown AIDA-1 expression in rat primary hippocampal neuronal cultures. We characterized two AIDA-1 targeting shRNAs ( shAIDA\# 1 and shAIDA\#2), either of which robustly downregulated AIDA-1 expression compared with a nontargeting shRNA control (shNT; Fig. 5A). We then performed immunocytochemistry to quantify the abundance of GluN2 subunits at synaptic junctions. As expected, knockdown of AIDA-1 decreased GluN2B and increased GluN2A distribution at synapses as assessed by colocalization with the synaptic marker Shank (Fig. $5 B, C)$. Both AIDA-1-targeting shRNAs led to similar results compared with shNT, suggesting that off-target effects were unlikely (Fig. 5B).

We also recorded from neurons transduced with lentiviral shRNAs as identified by GFP expression and found that the decay time constant of NMDAR-mediated EPSCs (Fig. 5D) as well as the sensitivity to Ro25-6981 (Fig. 5E) were decreased in neurons expressing shAIDA\#2 compared with shNT neurons. Phenotypes

\footnotetext{
cK0 mice compared with WT mice (WT, $62.2 \pm 2.4 \%$ of baseline; cK0, $75.9 \pm 2.3 \%$ of baseline). $\boldsymbol{B}$, Averaged sample traces (top) and summary data (bottom) showing that NMDAR-EPSCS in AIDA-1 CKO mice are more sensitive to the selective GluN2A antagonist $\mathrm{Zn}^{2+}$ (200 nM) compared with WT mice (WT, $69.2 \pm 2.5 \%$ of baseline; $\mathrm{CKO}, 48.7 \pm 2.7 \%$ of baseline). In all panels, averaged sample traces were taken at times indicated by numbers on the summary plot. The number of cells ( $(c)$, slices (s), and animals (a) are indicated in parentheses. $C$, Western blots and quantification showing unchanged expression of different synaptic proteins in whole hippocampal lysates from WT and AIDA-1 CKO mice ( $n=4-10$ mice; AIDA-1, $19.6 \pm$ $4.5 \%$ of WT, $n=8$ mice). $\boldsymbol{D}$, Western blots and quantification ( $n=3-10$ mice) showing a decrease in GluN2B (GluN2B, $70.4 \pm 12.3 \%$ of WT, $n=8$ ), an increase in GluN2A (GluN2A, $153.0 \pm 29.7 \%$ of WT, $n=8$ mice) and decrease in PSD95 (PSD95, $83.19 \pm$ $5.8 \%$ of WT, $n=4$ ) protein abundance in hippocampal PSD fractions from AIDA-1 CKO mice. ${ }^{*} p<0.05,{ }^{* * *} p<0.001$. Summary data represent the mean \pm SEM. All experiments were performed using mice aged P35-P48.
} 
A
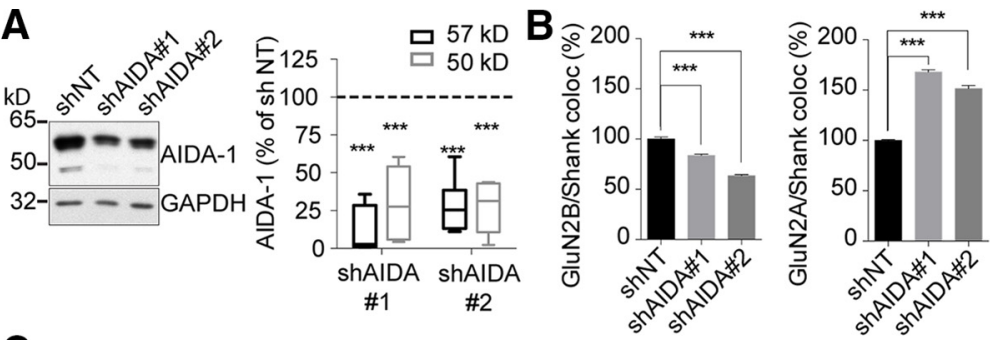

C shNT
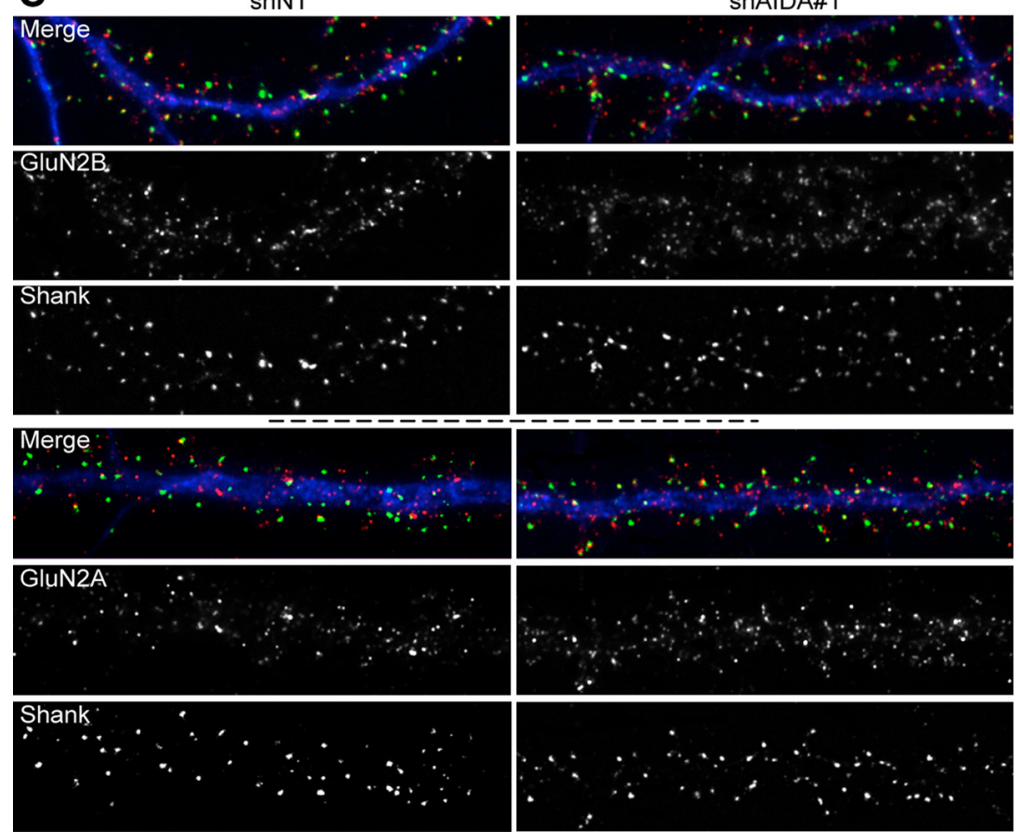

D shNT

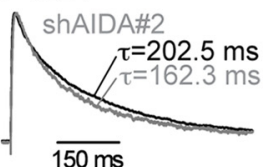

E shNT

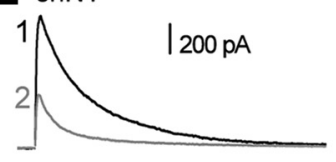

shAIDA\#2
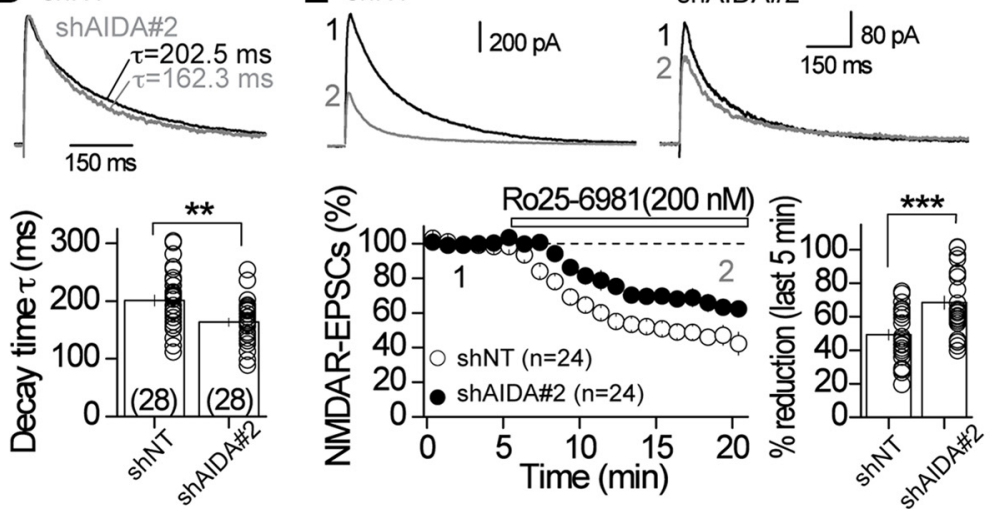

Figure 5. shRNA-mediated knockdown of AIDA-1 alters synaptic NMDAR subunit composition in rat primary neurons. $\boldsymbol{A}$, Left, Western blot showing reduction of AIDA-1 protein levels in cultured rat cortical neurons by two different AIDA-1-targeting shRNAs (shAIDA\#1 and shAIDA\#2) compared with a nontargeting control (shNT). Neurons were transduced with lentiviruses expressing shRNAs at 8 DIV for 7-12 d. Right, Quantification of shRNA-induced knockdown of AIDA-1 splice variants (57 and $50 \mathrm{kDa}$ ) and normalized to control (shNT): (shAIDA\#1: [57 kDa], $12.2 \pm 5.2 \%$; [50 kDa], $29.7 \pm 10.2 \%$; shAIDA\#2: [57 kDa], 28.1 $\pm 6.0 \%$; [50 $\mathrm{kDa}], 27.5 \pm 7.1 \% ; n=6-8$ samples from 3 different cultures). Statistical significance was determined using one-way ANOVA and post hoc $t$ test (2-tailed, unpaired) with Tukey's correction for multiple comparisons. B, Quantification for the mean intensity of GluN2B puncta (shAIDA\#1, 81.6 $\pm 1.0 \%$ of shNT; shAIDA\#2, $62.7 \pm 1.0 \%$ of shNT), or GluN2A puncta (shAIDA\#1, $156.4 \pm 1.7 \%$ of shNT; shAIDA\#2, $152.1 \pm 1.5 \%$ of shNT) that colocalized with the synaptic marker Shank ( $n=6-11$ cells from 3 independent cultures). Neurons were transduced on DIV 7 and imaged on DIV 17-22. C, Representative images showing that AIDA-1 knockdown reduces synaptic levels of GluN2B and increases synaptic levels of GluN2A in DIV 21 rat primary hippocampal cultures. GluN2 subunit is red, shank is green, and MAP2 is blue in the merged image. $D$, Representative normalized NMDAR-EPSCs (top) and summary data (bottom) showing that shRNA-mediated knockdown of AIDA-1 accelerates the decay kinetics of NMDAR-EPSCS (shNT, $201.0 \pm 9.4 \mathrm{~ms}$; shAIDA\#2, $163.5 \pm 6.9 \mathrm{~ms}, n=24$ cells from 6 independent cultures). $\boldsymbol{E}$, Averaged sample traces (top) and summary data (bottom) showing that shRNA-mediated knockdown of AIDA-1 decreased NMDAR-EPSC sensitivity to the GluN2Bspecific antagonist Ro25-6981 ( $200 \mathrm{~nm}$; shNT, $49.3 \pm 3.2 \%$; shAIDA\#2, $68.5 \pm 4.0 \% ; n=24$ cells from 6 independent cultures). Neurons were transduced at DIV 7 and recorded at DIV 12-21. Summary graphs represent the mean \pm SEM. ${ }^{* *} p<0.01,{ }^{* * *} p<$ 0.001 . observed in primary neuronal cultures suggest that impaired NMDAR transmission in AIDA-1 cKO mice is not due to compensatory mechanisms. Altogether, both cKO and shRNA approaches strongly support an essential role for AIDA-1 in the regulation of GluN2A/ GluN2B subunit composition at hippocampal synapses.

Loss of AIDA-1 impairs NMDARdependent synaptic plasticity at hippocampal Sch-CA1 synapses An increase in GluN2A/GluN2B ratio has been associated with a higher threshold for the induction of NMDAR-dependent LTP (NMDAR-LTP; Yashiro and Philpot, 2008; Paoletti et al., 2013). Consistent with this notion, NMDAR-LTP induced either by HFS (Fig. 6A) or TBS (Fig. 6B) was reduced at hippocampal Sch-CA1 synapses in AIDA-1 cKO mice compared with WT littermates. Moreover, we found that NMDAR-dependent LTD induced by low-frequency stimulation (Fig. $6 C$ ), but not mGluR-dependent LTD (Fig. 6D), was also reduced in AIDA-1 cKO mice. Together, these results strongly suggest that AIDA-1 plays an important role in NMDAR-dependent synaptic plasticity in the hippocampus by regulating NMDAR subunit composition.

AIDA-1 preferentially associates with GluN2B-containing NMDARs

The altered synaptic GluN2A/GluN2B ratio without a change in the total expression of GluN2A or GluN2B raises the possibility that AIDA-1 differentially regulates NMDAR subunit trafficking. To determine whether AIDA-1 interacts with NMDARs in a subunit-specific manner, we performed coimmunoprecipitation experiments from mouse hippocampal lysates. Consistent with previous work (Jordan et al., 2007), AIDA-1 bound to NMDARs and PSD95 but not AMPARs (Fig. 7A). By measuring the amount of GluN2 subunits coimmunoprecipitating with AIDA-1 and normalizing to total GluN2 subunit levels in the input, we found that AIDA- 1 associates preferentially with GluN2B over GluN2A (Fig. 7A). Similarly, immunocytochemical analysis showed that endogenous AIDA-1 colocalizes more with GluN2B than with GluN2A subunits in rat primary hippocampal neurons (Fig. $7 B, C$ ). Furthermore, overexpressed GFP-GluN2B and mKATE2-AIDA-1 colocalized extensively at synapses as well as in somatodendritic clusters in primary hippocampal cultures (Fig. 7D). Overexpressed GluN2A and AIDA-1 also colocalized in dendrites 
A WT

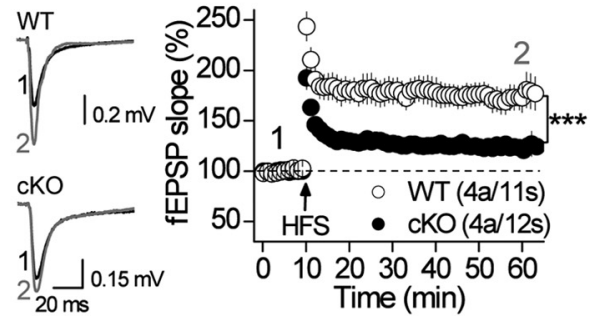

B

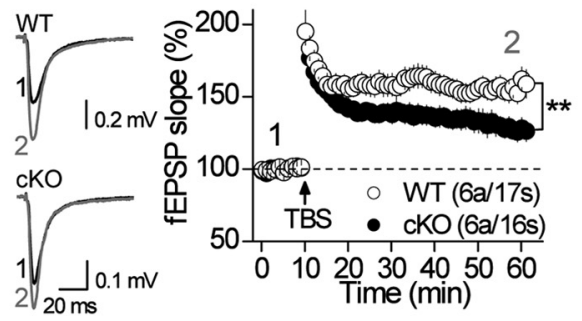

C ${ }_{1}^{\text {WT }}$
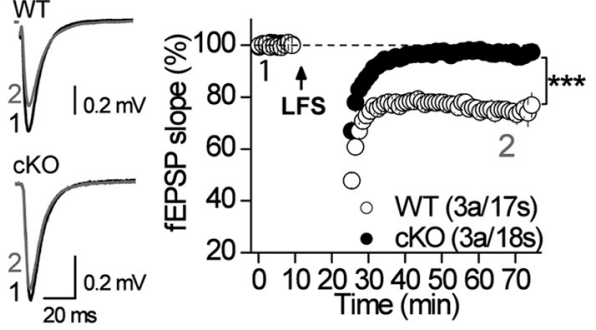

D WT
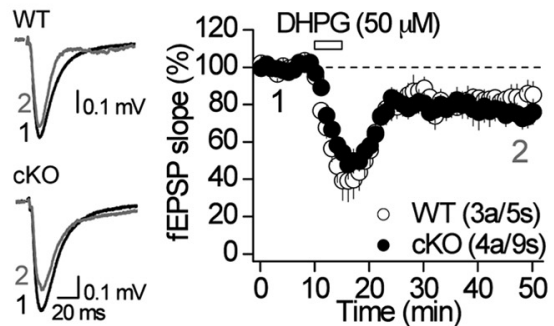

Figure 6. Impaired NMDAR-dependent plasticity at Sch-CA1 synapses in AIDA-1 CKO mice. $A$, Average traces (left) and summary plot (right) showing that LTP induced by HFS was impaired in AIDA-1 cKO compared with WT mice (last 10 min of HFS-LTP: WT, $173.5 \pm 11.2 \%$ of baseline; $\mathrm{CKO}, 128 \pm 4.8 \%$ of baseline). $B$, Similar results were observed by inducing LTP with TBS (last 10 min of TBS-LTP: WT, $153.7 \pm 6.2 \%$ of baseline; CK0, $128.8 \pm 7.2 \%$ of baseline). $C$, Average traces (left) and summary plot (right) showing that NMDAR-LTD induced by lowfrequency stimulation (LFS) was absent in AIDA-1 cK0 compared with WT mice (LFS; last 10 min: WT, $74.8 \pm 3.4 \%$ of baseline; (K0, $97.2 \pm 3.1 \%$ of baseline). $\boldsymbol{D}$, mGluR-LTD induced by application of group I mGluR agonist (S)-3,5-dihydroxyphenylglycine (DHPG) is normal in AIDA-1 cK0 mice (mGluR-LTD; last $10 \mathrm{~min}$ : WT, $83.6 \pm 5.9 \%$ of baseline; $\mathrm{CKO}, 75.7 \pm 6.6 \%$ of baseline, $p=0.753)$. In all panels, averaged sample traces were taken at times indicated by numbers on the summary plot. Summary data represent the mean \pm SEM and the number of slices $(s)$ and animals (a) are indicated in parentheses; ${ }^{* *} p<0.001,{ }^{* *} p=0.012$. Experiments were performed using mice at P35-P48.

but to a lesser extent (Fig. 7D). To determine whether AIDA-1 could interact with GluN2B, we coexpressed AIDA-1, GluN1, and GluN2B in HEK293FT cells. However, we could not detect an interaction between AIDA-1 and GluN2B using coimmunoprecipitations (Fig. 7E). This indicates that either AIDA-1 does not bind to GluN2B directly or specific conditions or factors exist in neurons that enable the formation of GluN2B-AIDA complexes. Together, these results suggest that AIDA-1 primarily associates with and controls the localization of GluN2B-containing NMDARs.

\section{AIDA-1 interacts with the GluN2B transport complex and regulates GluN2B ER export}

The extensive colocalization of AIDA-1 and GluN2B in somatodendritic compartments (Fig. 7D) implies that AIDA-1 regulates trafficking of GluN2B throughout the secretory pathway. We therefore asked whether AIDA-1 interacts with MAGUK family members SAP97 and CASK, and/or the kinesin-2 molecular motor KIF17, which regulate the ER export and transport of GluN2B-containing NMDARs to synapses (Setou et al., 2000; Guillaud et al., 2003; Lau and Zukin, 2007; Jeyifous et al., 2009). We found that AIDA-1 formed complexes with CASK and SAP97, as well as with the GluN2B molecular motor KIF17, but not with KIF1b (Fig. 8A). Moreover, we found that AIDA-1 bound to CASK and KIF17 when coexpressed in HEKs, suggesting a direct interaction (Fig. $8 B$ ). As acute knockdown of CASK or KIF17 have also been shown to reduce synaptic GluN2B levels (Guillaud et al., 2003; Jeyifous et al., 2009), we asked whether loss of AIDA-1 altered the levels of these proteins, but found no significant changes (Fig. $8 C$ ).

Because CASK and KIF17 transport GluN2B-containing NMDARs in ER-derived vesicles (Jeyifous et al., 2009), we reasoned that loss of AIDA-1 might lead to the accumulation of GluN2B in the ER. We therefore performed subcellular fractionation of AIDA-1 cKO and WT hippocampal tissues using iodixanol gradient centrifugation to obtain enriched Golgi and ER fractions. As expected, the ER marker calnexin was enriched in heavier fractions while the Golgi marker $58 \mathrm{~K}$ protein was enriched in lighter fractions (Fig. $8 D$ ). Densitometry-based quantification indicated that GluN2B levels were significantly increased in calnexin-positive ER fractions from AIDA-1 cKO mice compared with controls (Fig. $8 D$ ). Together these results show that GluN2B accumulates in the ER in the absence of AIDA-1 and are consistent with a role for AIDA-1 in the ER export of GluN2Bcontaining NMDARs.

\section{Discussion}

Here we report a previously unknown role for AIDA-1 in the regulation of synaptic NMDAR subunit composition and NMDAR-dependent plasticity in the hippocampus. Using a forebrain-specific AIDA-1 cKO mouse and a knockdown strategy, we demonstrate that loss of AIDA-1 decreases GluN2Bmediated and increases GluN2A-mediated synaptic transmission without affecting the total protein abundance of either subunit, consistent with a dysregulation of GluN2 subunit trafficking. We also showed that AIDA-1 preferentially associates with GluN2Bcontaining NMDARs and plays a role in their transport from the ER. To our knowledge, our findings provide the first evidence that AIDA-1 can control NMDAR subunit composition and synaptic function by regulating GluN2B distribution.

The basis for the preferential association between AIDA-1 and GluN2B over GluN2A is unclear. While AIDA-1 associates with GluN2B in hippocampal tissue, this does not appear to be a direct interaction (Fig. 7E). Among candidate intermediary proteins are MAGUKs that bind to both NMDARs and AIDA-1 (Kim and Sheng, 2004; Jordan et al., 2007; Lau and Zukin, 2007), and which may exhibit GluN2 subunit selectivity, although this latter view remains controversial (Paoletti et al., 2013). AIDA-1 could also interact with PDZ domain-containing adaptors, such as MALS-2, which binds to the GluN2B C-terminal domain and increases the surface expression of GluN2B but not GluN2A (Jo et al., 1999; Iwamoto et al., 2004). Another candidate is amyloid precursor protein, which binds to both AIDA-1 (Ghersi et al., 2004a,b) and NMDARs (Cousins et al., 2009) and regulates cell-surface 
A

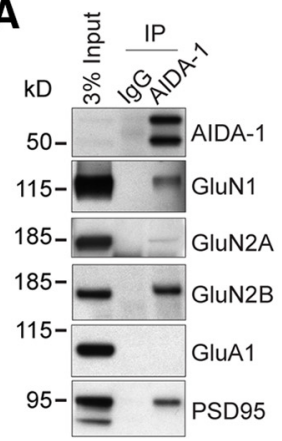

C
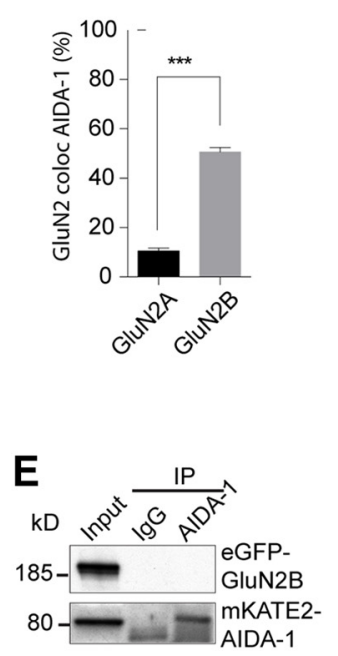

B
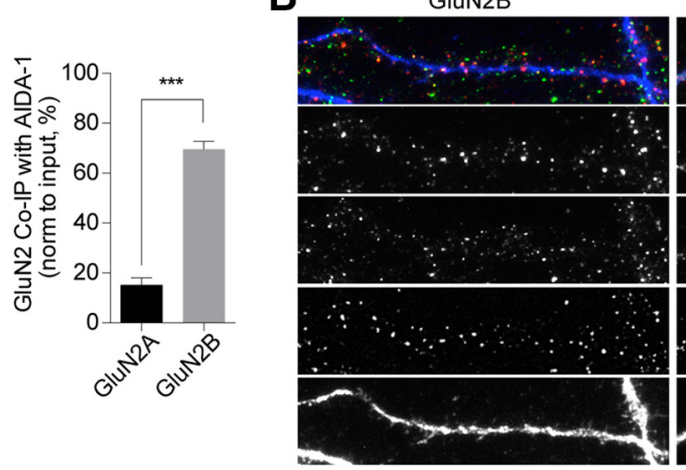

D

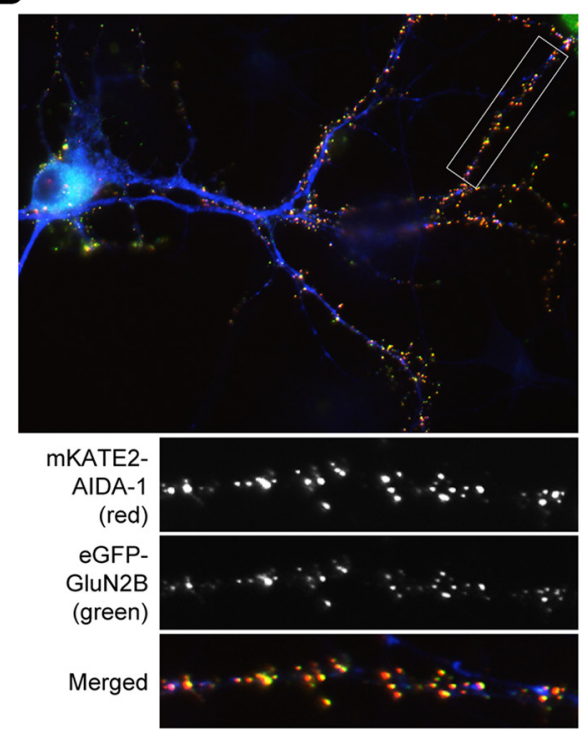

GluN2A

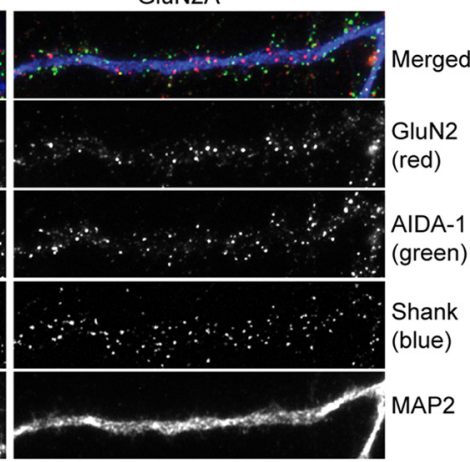

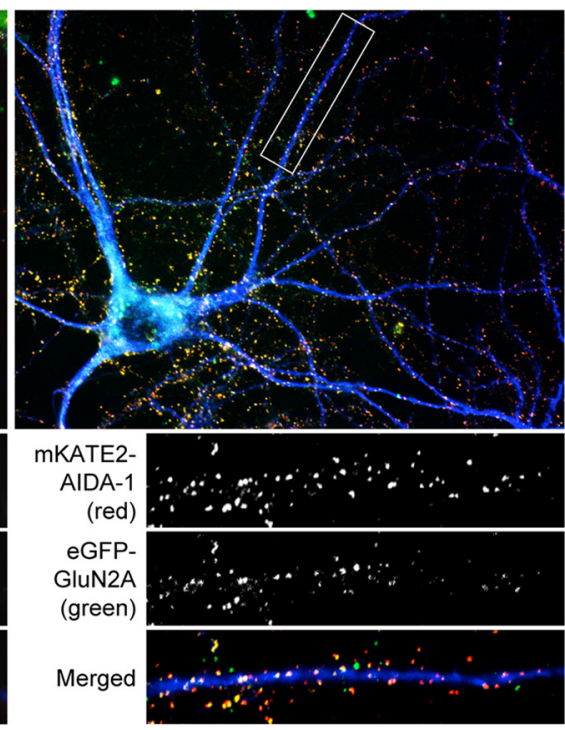

Figure 7. AIDA-1 preferentially associates with GluN2B-containing NMDARs. A, Coimmunoprecipitations from mouse whole hippocampal lysates prepared at P42 show that AIDA-1 interacts with GluN1, with PSD95, and preferentially with GluN2B over GluN2A. The extent of GluN2B or GluN2A binding to AIDA-1 was determined by normalizing the immunoprecipitation (IP) signal by the input ( $n=5$ independent coimmunoprecipitations; input, $15 \mu \mathrm{g}$; GluN2B, $69.5 \pm 3.3 \%$; GluN2A, $10.5 \pm 1.2 \%$ ). B. Primary rat hippocampal neurons at DIV 21 were immunostained for the dendritic marker MAP2, synaptic marker Shank, AIDA-1, and GluN2A or GluN2B. C, The extent of colocalization of AIDA-1 with GluN2A or GluN2B was quantified by Mander's coefficients, and shows that AIDA- 1 colocalizes preferentially with GluN2B ( $n=6-8$ cells from 4 independent cultures; GluN2A-AIDA, $10.5 \pm 1.2 \%$; GluN2B-AIDA, $50.6 \pm 1.8 \%$ ). D, Coexpression of GluN2B (eGFP-GluN2B) or GluN2A (eGFP-GluN2A) with AIDA-1 (57 kDa isoform; mKATE2, a red fluorescent protein) in rat primary hippocampal neurons at DIV 14 for $3 \mathrm{~d}$ shows extensive colocalization of AIDA-1 and GluN2B in dendrites, and much less with GluN2A. $E$, Representative Western blot showing AIDA-1 isoform and GluN2B do not coimmunoprecipitate when coexpressed in HEK293FT cells. Data presented as mean \pm SEM. ${ }^{* * *} p<0.001$.

GluN2B levels in neurons without affecting surface GluN2A expression (Hoe et al., 2009). Although we cannot rule out a direct role for AIDA-1 in controlling GluN2A levels at synapses, our imaging and quantitative coimmunoprecipitations support a direct role for AIDA-1 in regulating GluN2B. Previous findings show that GluN2A can compensate for the loss of GluN2B at synapses (Barria and Malinow, 2002), raising the possibility that upregulation of synaptic GluN2A represents a compensatory effect in AIDA- 1 cKO mice. Still, $\sim 20 \%$ of GluN2A associates with AIDA-1 by immunoprecipitation and immunofluorescence analysis (Fig. 7A-D), suggesting AIDA-1 binding to GluN1/ GluN2A/GluN2B triheterotrimeric NMDARs (Paoletti et al., 2013; Tovar et al., 2013).

We found that loss of AIDA-1 leads to the accumulation of GluN2B in the ER. Mechanisms governing NMDAR export from the ER include alternative splicing of GluN1 subunits (Scott et al., 2001) and masking of C-terminal ER-retention motifs by the binding of PDZ-domain-containing proteins (Wenthold et al., 2003a). We previously reported that AIDA-1 binds to the NMDAR complex and can accumulate in the nucleus following
NMDAR activity (Jordan et al., 2007). While a role for altered gene expression or nucleolar function cannot be excluded, we found no changes in the overall abundance of factors involved in NMDAR expression or trafficking (Fig. 8C). Instead, we provide evidence that AIDA- 1 associates with SAP97, CASK, and the molecular motor KIF17, which are components of a complex critically involved in GluN2B transport from the ER (Jeyifous et al., 2009) and trafficking along dendrites to synapses (Setou et al., 2000; Guillaud et al., 2003; Jeyifous et al., 2009). Remarkably, knockdown of SAP97 or CASK leads to GluN2B accumulation in the soma (Jeyifous et al., 2009). Moreover, acute loss of KIF17 reduces the dendritic transport of GluN2B, decreases synaptic GluN2B, and increases GluN2A levels (Guillaud et al., 2003), exactly phenocopying the synaptic alteration of NMDAR subunits in AIDA-1 cKO mice. Altogether these results strongly suggest that AIDA- 1 is a functional component of the CASK/KIF17 complex that regulates the ER export and trafficking of GluN2B to synapses.

Precisely how AIDA-1 regulates the CASK/KIF17 complex and GluN2B export from the ER is unclear. AIDA-1 may act as an adaptor that sorts cargos from the ER to vesicles for transport. In 
support of this possibility, the PTB domain of AIDA-1 is 45\% homologous to the PTB domain of Dab2, which regulates the endocytosis of lipoprotein receptorrelated proteins and recognizes inositide4,5-bisphosphates, which are enriched in membrane subdomains that undergo increased rates of endocytosis (Mishra et al., 2002). Alternatively, ubiquitination has emerged as an elaborate cellular mechanism for sorting proteins into different subcellular compartments (Hicke and Dunn, 2003). The sterile- $\alpha$-motif domains of the AIDA-1 homolog Odin can bind to ubiquitinated EphA8 receptors and prevent their internalization (Kim et al., 2010). As GluN2B is ubiquitinated by the E3 ligase Mindbomb-2 (Jurd et al., 2008), AIDA-1 may bind to ubiquitinated GluN2B and regulate its localization, although we were unable to detect a direct interaction between AIDA-1 and GluN2B expressed in heterologous cells.

An alternative hypothesis to ER export and sorting is that AIDA-1 stabilizes GluN2B-containing NMDARs at synaptic sites similar to MAGUKs (Kim and Sheng, 2004). This possibility is consistent with biochemical and electron microscopy evidence showing that AIDA-1 is enriched and localized within the core of the PSD (Jordan et al., 2004, 2007; Dosemeci et al., 2007; Jacob et al., 2010). Yet another possibility is that AIDA-1 stabilizes GluN2B at synapses indirectly through PSD-95, as PSD-95 can control surface expression of AMPARs and NMDARs (Elias and Nicoll, 2007; Xu, 2011) and loss of AIDA-1 reduces synaptic levels of PSD-95 (Fig. 4D). However, neither AMPAR mEPSCs, nor input/output of AMPAR-mediated transmission, nor AMPAR subunits at the PSD are altered in AIDA-1 cKO mice. Therefore the significance of reduced PSD95 expression at synapses will require additional experimentation. Studies on glutamatergic receptor trafficking have shown that it is difficult to assign distinct roles to receptor adaptor proteins (Paoletti et al., 2013). For example, MAGUKs, which stabilize and cluster AMPARs and NMDARs at synapses, have also been observed throughout the secretory pathway and promote ER export (Wenthold et al., 2003b). Additional experiments will therefore be required to determine the precise molecular mechanisms underlying the AIDA-1-dependent regulation of GluN2B ER export, transport, and localization at synapses.

Several human studies have linked the AIDA-1 gene ANKS1B to schizophrenia and ASDs. A recent large exome sequencing study identified small de novo mutations in ANKS1B in patients with schizophrenia (Fromer et al., 2014; Purcell et al., 2014), and a single nucleotide polymorphism (SNP) in ANKS1B has been associated with improved response to antipsychotics, such as olanzapine and respiridone (McClay et al., 2011a,b). In addition, copy number variations and SNPs in $A N K S 1 B$ have also been ${ }^{*} p<0.05$.
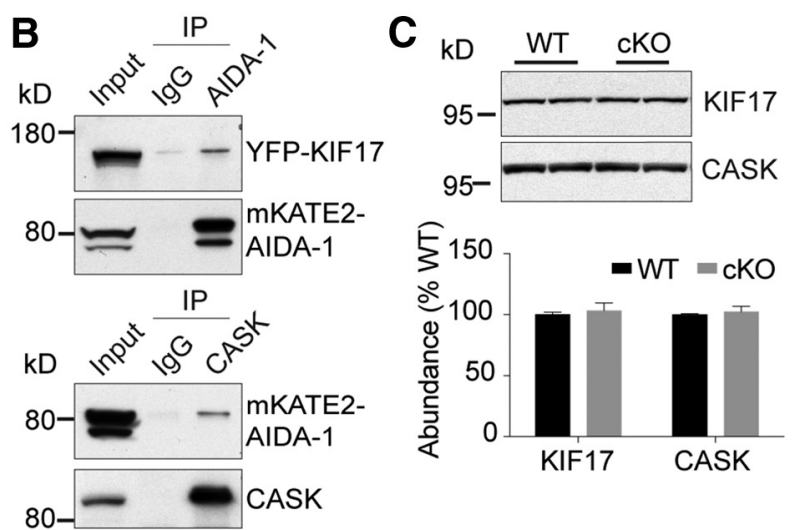

$\mathrm{CKO}$

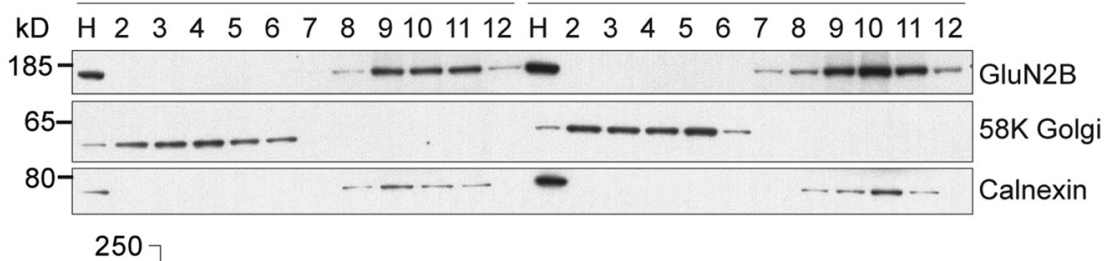

Figure 8. AIDA-1 associates with the GluN2B transport machinery and regulates GluN2B export from the ER. $A$, Coimmunoprecipitations from whole mouse hippocampus showing that AIDA-1 associates with components of the GluN2B transport machinery (h. Coimmunoprecipitations show that AIDA-1 can interact with both KIF17 and CASK. C, Loss of AIDA-1 does not alter the total pal tissue of WT and AIDA-1 CKO mice. H represents whole lysate. Below, A plot of the relative abundance of GluN2B in consecutive (a) 0.024). Results show GluN2B accumulates in the ER fractions in AIDA-1 CKO mice. Summary graphs represent the mean \pm SEM.

identified in patients with autism (Pinto et al., 2010) and correlate positively with impaired play skills (Hu et al., 2011; Meehan et al., 2011). Furthermore, ANKS1B contains "brain-critical" exons that are enriched in autism (Uddin et al., 2014). Despite these important links to disease, how altered AIDA-1 function may contribute to neuropsychiatric disorders is unknown. One possibility is that impaired NMDAR-dependent LTP and LTD contributes to cognitive deficits present in diseases associated with AIDA-1 dysfunction. NMDAR dysfunction has been implicated in schizophrenia (Lau and Zukin, 2007; McClay et al., 2011b; Poot et al., 2011; Paoletti et al., 2013; Snyder and Gao, 2013; Fromer et al., 2014; Purcell et al., 2014), ASD (Poot et al., 2011; Tarabeux et al., 2011; Jiang and Ehlers, 2013; Palumbo et al., 2014), and Alzheimer's disease (AD; Lau and Zukin, 2007; Mota et al., 2014). GluN2B (GRIN2B), in particular, has been identified as a candidate gene in genome-wide association studies of patients with sporadic ASD (Poot et al., 2011) and deletions or copy number variations of GluN2B regulating factors, such as SHANK 
(Jiang and Ehlers, 2013) and TBR1 (Palumbo et al., 2014), have been reported in patients with ASD. In $\mathrm{AD}$, synaptic alterations induced by amyloid- $\beta$ are mediated by NMDARs, especially GluN2B-containing NMDARs (Mota et al., 2014). Although more evidence is required, our finding that AIDA- 1 regulates NMDAR function by controlling synaptic GluN2B levels raises the possibility that mutations in AIDA-1 might contribute to the pathogenesis of these neuropsychiatric disorders by impairing GluN2B function.

\section{References}

Barria A, Malinow R (2002) Subunit-specific NMDA receptor trafficking to synapses. Neuron 35:345-353. CrossRef Medline

Cousins SL, Hoey SE, Anne Stephenson F, Perkinton MS (2009) Amyloid precursor protein 695 associates with assembled NR2A- and NR2Bcontaining NMDA receptors to result in the enhancement of their cell surface delivery. J Neurochem 111:1501-1513. CrossRef Medline

Cull-Candy SG, Leszkiewicz DN (2004) Role of distinct NMDA receptor subtypes at central synapses. Sci STKE 2004:re16. Medline

Dosemeci A, Makusky AJ, Jankowska-Stephens E, Yang X, Slotta DJ, Markey SP (2007) Composition of the synaptic PSD-95 complex. Mol Cell Proteomics 6:1749-1760. Medline

Elias GM, Nicoll RA (2007) Synaptic trafficking of glutamate receptors by MAGUK scaffolding proteins. Trends Cell Biol 17:343-352. Medline

Fromer M, Pocklington AJ, Kavanagh DH, Williams HJ, Dwyer S, Gormley P, Georgieva L, Rees E, Palta P, Ruderfer DM, Carrera N, Humphreys I, Johnson JS, Roussos P, Barker DD, Banks E, Milanova V, Grant SG, Hannon E, Rose SA, et al. (2014) De novo mutations in schizophrenia implicate synaptic networks. Nature 506:179-184. CrossRef Medline

Ghersi E, Vito P, Lopez P, Abdallah M, D'Adamio L (2004a) The intracellular localization of amyloid beta protein precursor (AbetaPP) intracellular domain associated protein-1 (AIDA-1) is regulated by AbetaPP and alternative splicing. J Alzheimers Dis 6:67-78. Medline

Ghersi E, Noviello C, D’Adamio L (2004b) Amyloid-beta protein precursor (AbetaPP) intracellular domain-associated protein-1 proteins bind to AbetaPP and modulate its processing in an isoform-specific manner. J Biol Chem 279:49105-49112. Medline

Graham JM (2001) Isolation of Golgi membranes from tissues and cells by differential and density gradient centrifugation. Curr Protoc Cell Biol Chapter 3:Unit 3.9. CrossRef Medline

Guillaud L, Setou M, Hirokawa N (2003) KIF17 dynamics and regulation of NR2B trafficking in hippocampal neurons. J Neurosci 23:131-140. Medline

Hicke L, Dunn R (2003) Regulation of membrane protein transport by ubiquitin and ubiquitin-binding proteins. Annu Rev Cell Dev Biol 19: 141-172. Medline

Hoe HS, Fu Z, Makarova A, Lee JY, Lu C, Feng L, Pajoohesh-Ganji A, Matsuoka Y, Hyman BT, Ehlers MD, Vicini S, Pak DT, Rebeck GW (2009) The effects of amyloid precursor protein on postsynaptic composition and activity. J Biol Chem 284:8495-8506. CrossRef Medline

Hu VW, Addington A, Hyman A (2011) Novel autism subtype-dependent genetic variants are revealed by quantitative trait and subphenotype association analyses of published GWAS data. PloS One 6:e19067. CrossRef Medline

Iwamoto T, Yamada Y, Hori K, Watanabe Y, Sobue K, Inui M (2004) Differential modulation of NR1-NR2A and NR1-NR2B subtypes of NMDA receptor by PDZ domain-containing proteins. J Neurochem 89:100-108. CrossRef Medline

Jacob AL, Jordan BA, Weinberg RJ (2010) Organization of amyloid-beta protein precursor intracellular domain-associated protein-1 in the rat brain. J Comp Neurol 518:3221-3236. CrossRef Medline

Jeyifous O, Waites CL, Specht CG, Fujisawa S, Schubert M, Lin EI, Marshall J, Aoki C, de Silva T, Montgomery JM, Garner CC, Green WN (2009) SAP97 and CASK mediate sorting of NMDA receptors through a previously unknown secretory pathway. Nat Neurosci 12:1011-1019. CrossRef Medline

Jiang YH, Ehlers MD (2013) Modeling autism by SHANK gene mutations in mice. Neuron 78:8-27. CrossRef Medline

Jo K, Derin R, Li M, Bredt DS (1999) Characterization of MALS/Velis-1, -2, and -3: a family of mammalian LIN-7 homologs enriched at brain syn- apses in association with the postsynaptic density-95/NMDA receptor postsynaptic complex. J Neurosci 19:4189-4199. Medline

Jordan BA, Fernholz BD, Boussac M, Xu C, Grigorean G, Ziff EB, Neubert TA (2004) Identification and verification of novel rodent postsynaptic density proteins. Mol Cell Proteomics 3:857-871. Medline

Jordan BA, Fernholz BD, Khatri L, Ziff EB (2007) Activity-dependent AIDA-1 nuclear signaling regulates nucleolar numbers and protein synthesis in neurons. Nat Neurosci 10:427-435. Medline

Jurd R, Thornton C, Wang J, Luong K, Phamluong K, Kharazia V, Gibb SL, Ron D (2008) Mind bomb-2 is an E3 ligase that ubiquitinates the $\mathrm{N}$-methyl-D-aspartate receptor NR2B subunit in a phosphorylationdependent manner. J Biol Chem 283:301-310. Medline

Kim E, Sheng M (2004) PDZ domain proteins of synapses. Nat Rev Neurosci 5:771-781. Medline

Kim J, Lee H, Kim Y, Yoo S, Park E, Park S (2010) The SAM domains of Anks family proteins are critically involved in modulating the degradation of EphA receptors. Mol Cell Biol 30:1582-1592. CrossRef Medline

Lau CG, Zukin RS (2007) NMDA receptor trafficking in synaptic plasticity and neuropsychiatric disorders. Nat Rev Neurosci 8:413-426. Medline

Loftis JM, Janowsky A (2003) The N-methyl-D-aspartate receptor subunit NR2B: localization, functional properties, regulation, and clinical implications. Pharmacol Ther 97:55-85. Medline

McClay JL, Adkins DE, Aberg K, Stroup S, Perkins DO, Vladimirov VI, Lieberman JA, Sullivan PF, van den Oord EJ (2011a) Genome-wide pharmacogenomic analysis of response to treatment with antipsychotics. Mol Psychiatry 16:76-85. CrossRef Medline

McClay JL, Adkins DE, Aberg K, Bukszár J, Khachane AN, Keefe RS, Perkins DO, McEvoy JP, Stroup TS, Vann RE, Beardsley PM, Lieberman JA, Sullivan PF, van den Oord EJ (2011b) Genome-wide pharmacogenomic study of neurocognition as an indicator of antipsychotic treatment response in schizophrenia. Neuropsychopharmacology 36:616-626. CrossRef Medline

Meehan TF, Carr CJ, Jay JJ, Bult CJ, Chesler EJ, Blake JA (2011) Autism candidate genes via mouse phenomics. J Biomed Inform 44 [suppl 1]:S5S11. CrossRef Medline

Mishra SK, Keyel PA, Hawryluk MJ, Agostinelli NR, Watkins SC, Traub LM (2002) Disabled-2 exhibits the properties of a cargo-selective endocytic clathrin adaptor. EMBO J 21:4915-4926. Medline

Moghaddam B, Javitt D (2012) From revolution to evolution: the glutamate hypothesis of schizophrenia and its implication for treatment. Neuropsychopharmacology 37:4-15. CrossRef Medline

Mota SI, Ferreira IL, Rego AC (2014) Dysfunctional synapse in Alzheimer's disease - a focus on NMDA receptors. Neuropharmacology 76:16-26. CrossRef Medline

Osten P, Khatri L, Perez JL, Köhr G, Giese G, Daly C, Schulz TW, Wensky A, Lee LM, Ziff EB (2000) Mutagenesis reveals a role for ABP/GRIP binding to GluR2 in synaptic surface accumulation of the AMPA receptor. Neuron 27:313-325. CrossRef Medline

Palumbo O, Fichera M, Palumbo P, Rizzo R, Mazzolla E, Cocuzza DM, Carella M, Mattina T (2014) TBR1 is the candidate gene for intellectual disability in patients with a 2q24.2 interstitial deletion. Am J Med Genet A 164A:828-833. CrossRef Medline

Paoletti P, Bellone C, Zhou Q (2013) NMDA receptor subunit diversity: impact on receptor properties, synaptic plasticity and disease. Nat Rev Neurosci 14:383-400. CrossRef Medline

Pinto D, Pagnamenta AT, Klei L, Anney R, Merico D, Regan R, Conroy J, Magalhaes TR, Correia C, Abrahams BS, Almeida J, Bacchelli E, Bader GD, Bailey AJ, Baird G, Battaglia A, Berney T, Bolshakova N, Bölte S, Bolton PF, et al. (2010) Functional impact of global rare copy number variation in autism spectrum disorders. Nature 466:368-372. CrossRef Medline

Poot M, van der Smagt JJ, Brilstra EH, Bourgeron T (2011) Disentangling the myriad genomics of complex disorders, specifically focusing on autism, epilepsy, and schizophrenia. Cytogenet Genome Res 135:228-240. CrossRef Medline

Purcell SM, Moran JL, Fromer M, Ruderfer D, Solovieff N, Roussos P, O'Dushlaine C, Chambert K, Bergen SE, Kähler A, Duncan L, Stahl E, Genovese G, Fernández E, Collins MO, Komiyama NH, Choudhary JS, Magnusson PK, Banks E, Shakir K, et al. (2014) A polygenic burden of rare disruptive mutations in schizophrenia. Nature 506:185-190. CrossRef Medline

Sanz-Clemente A, Nicoll RA, Roche KW (2013) Diversity in NMDA recep- 
tor composition: many regulators, many consequences. Neuroscientist 19:62-75. CrossRef Medline

Scott DB, Blanpied TA, Swanson GT, Zhang C, Ehlers MD (2001) An NMDA receptor ER retention signal regulated by phosphorylation and alternative splicing. J Neurosci 21:3063-3072. Medline

Setou M, Nakagawa T, Seog DH, Hirokawa N (2000) Kinesin superfamily motor protein KIF17 and mLin-10 in NMDA receptor-containing vesicle transport. Science 288:1796-1802. CrossRef Medline

Snyder MA, Gao WJ (2013) NMDA hypofunction as a convergence point for progression and symptoms of schizophrenia. Front Cell Neurosci 7:31. CrossRef Medline

Tarabeux J, Kebir O, Gauthier J, Hamdan FF, Xiong L, Piton A, Spiegelman D, Henrion É, Millet B; S2D team, Fathalli F, Joober R, Rapoport JL, DeLisi LE, Fombonne É, Mottron L, Forget-Dubois N, Boivin M, Michaud JL, Drapeau P et al. (2011) Rare mutations in N-methyl-D-aspartate glutamate receptors in autism spectrum disorders and schizophrenia. Transl Psychiatry 1:e55. CrossRef Medline

Tovar KR, McGinley MJ, Westbrook GL (2013) Triheteromeric NMDA receptors at hippocampal synapses. J Neurosci 33:9150-9160. CrossRef Medline

Traynelis SF, Wollmuth LP, McBain CJ, Menniti FS, Vance KM, Ogden KK, Hansen KB, Yuan H, Myers SJ, Dingledine R (2010) Glutamate receptor ion channels: structure, regulation, and function. Pharmacol Rev 62:405496. CrossRef Medline
Tsien JZ, Chen DF, Gerber D, Tom C, Mercer EH, Anderson DJ, Mayford M, Kandel ER, Tonegawa S (1996) Subregion- and cell type-restricted gene knock-out in mouse brain. Cell 87:1317-1326. CrossRef Medline

Uddin M, Tammimies K, Pellecchia G, Alipanahi B, Hu P, Wang Z, Pinto D, Lau L, Nalpathamkalam T, Marshall CR, Blencowe BJ, Frey BJ, Merico D, Yuen RK, Scherer SW (2014) Brain-expressed exons under purifying selection are enriched for de novo mutations in autism spectrum disorder. Nat Genet 46:742-747. CrossRef Medline

Wenthold RJ, Prybylowski K, Standley S, Sans N, Petralia RS (2003a) Trafficking of NMDA receptors. Annu Rev Pharmacol Toxicol 43:335-358. Medline

Wenthold RJ, Sans N, Standley S, Prybylowski K, Petralia RS (2003b) Early events in the trafficking of N-methyl-D-aspartate (NMDA) receptors. Biochem Soc Trans 31:885-888. Medline

$\mathrm{Xu}$ H, Hebert MD (2005) A novel EB-1/AIDA-1 isoform, AIDA-1c, interacts with the Cajal body protein coilin. BMC Cell Biol 6:23. Medline

Xu W (2011) PSD-95-like membrane associated guanylate kinases (PSDMAGUKs) and synaptic plasticity. Curr Opin Neurobiol 21:306-312. CrossRef Medline

Yashiro K, Philpot BD (2008) Regulation of NMDA receptor subunit expression and its implications for LTD, LTP, and metaplasticity. Neuropharmacology 55:1081-1094. CrossRef Medline 